\title{
Student Teachers' Beliefs, Feelings and Attitudes toward Mathematics Learning and Teaching at the University of Trinidad and Tobago
}

\author{
Myrna Ransome ${ }^{1, *}$, Musa El Sharief Mohamed ${ }^{1} \&$ Puran Bridgemohan $^{2}$ \\ ${ }^{1}$ The Centre for Education Programmes, The University of Trinidad and Tobago, Valsayn Campus, Trinidad and \\ Tobago \\ ${ }^{2}$ Centre for Bioscience. The University of Trinidad and Tobago, Waterloo Campus, Trinidad and Tobago \\ *Correspondence: The University of Trinidad and Tobago, Centre for Education Programmes, Valsayn Campus, \\ Graver Road, Off Old Southern Main Road, Valsayn, Trinidad and Tobago. Tel: 1(868) 642-8888 Ext. 29108 E-mail: \\ myrna.ransome@utt.edu.tt
}

Received: July 17, 2016

Accepted: August 8, 2016 Online Published: August 23, 2016

doi:10.5430/wje.v6n4p38

URL: http://dx.doi.org/10.5430/wje.v6n4p38

\begin{abstract}
The colonial fallacy that only a few persons are endowed with the capabilities to conceptualize mathematics, coupled with the belief that society equates mathematical ability with intellectual superiority, have contributed to low levels of mathematical self-concept and achievement among some students of mathematics. Some of these students are required to teach the subject as primary and secondary school teachers. This paper examines the influence of student teachers' beliefs, feelings and attitudes towards mathematics on their learning and teaching of mathematics. The sample $(\mathrm{N}=165)$ comprises third and fourth year, male and female, full and part time students, who were enrolled in the 4 year Bachelor of Education Programme at the Centre of Education Programmes, University of Trinidad and Tobago. Data collection employed the use of the Fennema - Sherman 1976 Mathematics Attitudes Scale which was adapted to formulate a 13 item survey instrument - Mathematics Attitude Survey (MAS). Regression analyses using MANITAB statistical package indicate that beliefs, feelings and attitudes towards mathematics are determined by students' feelings, expectations and perceived usefulness of mathematics. Gender did not emerge as a factor.
\end{abstract}

Keywords: attitudes toward mathematics; feelings about mathematics; achievement in mathematics

\section{Introduction}

There are worldwide concerns related to success in Mathematics at primary, secondary and tertiary levels of education. A study to improve the teaching of mathematics conducted in the Caribbean by the National Institute of Higher Education, Research, Science and Technology (NIHERST) in 2006, revealed that most students experienced great difficulty doing mathematics. This observation was supported in 2012 when the Caribbean Examination Council (CXC) subject awards committee expressed the need to address performance in Mathematics at the Caribbean Secondary Education Certificate (CSEC) examination. At the 2012 May/June examination, only 33 per cent of candidates secured passing grades I-III somewhat similar to 35 per cent in 2011(Table 1). The committee indicated that "on one question which tested perimeter and area, 36 per cent of the candidates scored no marks. Similarly, on a question which tested algebra, 33 per cent of the candidates also scored zero" (Jacobs, 2012, p.1).

The NIHERST (2006) survey advised teachers that "the teaching and understanding of mathematics are essential to the total development of the student and by extension, impact directly on the level of numeracy in the population" (pp.1). Since good mathematics instruction is essential for a progressive society (Persad, 2009), preparation of quality teachers of mathematics is mandatory in any society. However, mathematics teachers' classroom practices are influenced by their beliefs, interests, past experiences which influence their attitudes to their learning and teaching of mathematics (Singh, Granville \& Dika, 2002).

\subsection{Students' Beliefs}

There is a perpetual fear associated with studying mathematics and this is coupled with the colonial belief that mathematics competence is an indicator of intelligence. There is also the perception that mathematics is irrelevant 
and not very useful to everyday living, and not as valuable as language. Hence, beliefs related to math incompetence result in frustration, phobia, anxiety as well as reduced effort and persistence (Gilroy, 2002). Beliefs however, are correlated with values, feelings and attitudes (Maasz \& Schloglmann, 2009).

Table 1. Caribbean Examination Council (CXC) Report on Performances by Caribbean Regional Candidates in the Caribbean Secondary Education Certificate (CSEC) Examination 2010-2015

\begin{tabular}{lllll}
\hline Year & $\begin{array}{l}\text { Approximate } \\
\text { Candidates Entry }\end{array}$ & $\begin{array}{l}\text { Percentage } \\
\text { Grades 1-III }\end{array}$ & Total Marks & Mean Score \\
\hline January 2015 & 9971 & $65 \%$ & 180 & Not Available \\
January 2014 & 11690 & $47 \%$ & 180 & 74 \\
May/June 2014 & 90100 & $50 \%$ & 180 & 75 \\
January 2013 & 12900 & $40 \%$ & 180 & 78 \\
May/June 2013 & 92400 & $35 \%$ & 180 & 65 \\
January 2012 & 14200 & $40 \%$ & 180 & 77.14 \\
May/June 2012 & 95000 & $33 \%$ & 180 & 66.40 \\
January 2011 & 13760 & $37 \%$ & 180 & 74.97 \\
May/June 2011 & 90000 & $35 \%$ & 180 & 71.43 \\
January 2010 & No Examination & & & \\
May/June 2010 & 88400 & $41 \%$ & 180 & 76.59 \\
\hline
\end{tabular}

https://www.cxc.org/?q=students-and-parents/exam-results-reports/exam-results-reports-csec

Paper 1 MC - 60 Marks $\quad$ Paper 2 - Structured Questions - 120 marks Total -180 marks

\section{Conceptual Framework}

Based on Ernest (1989) conceptual model, teachers' instructional practices are a function of their subject-matter knowledge, instructional beliefs, and mathematical attitudes. Teachers' attitudes related to mathematics, constitute both attitudes toward mathematics and attitudes toward teaching mathematics. In addition, teachers' previous school experiences and perceptions as students affect their beliefs and attitudes as teachers (Mapolelo \& Akinsola, 2015). While the majority of students with the highest examination grades may not select teaching as their career, there is no guarantee that a perfect score in mathematics constitutes excellent conceptual knowledge of mathematical content require for teaching (Akinsola, \& Ajiboye, 2009; Ball, Hill, \& Bass, 2005; Bramald, Hardman, \& Leat, 1995).

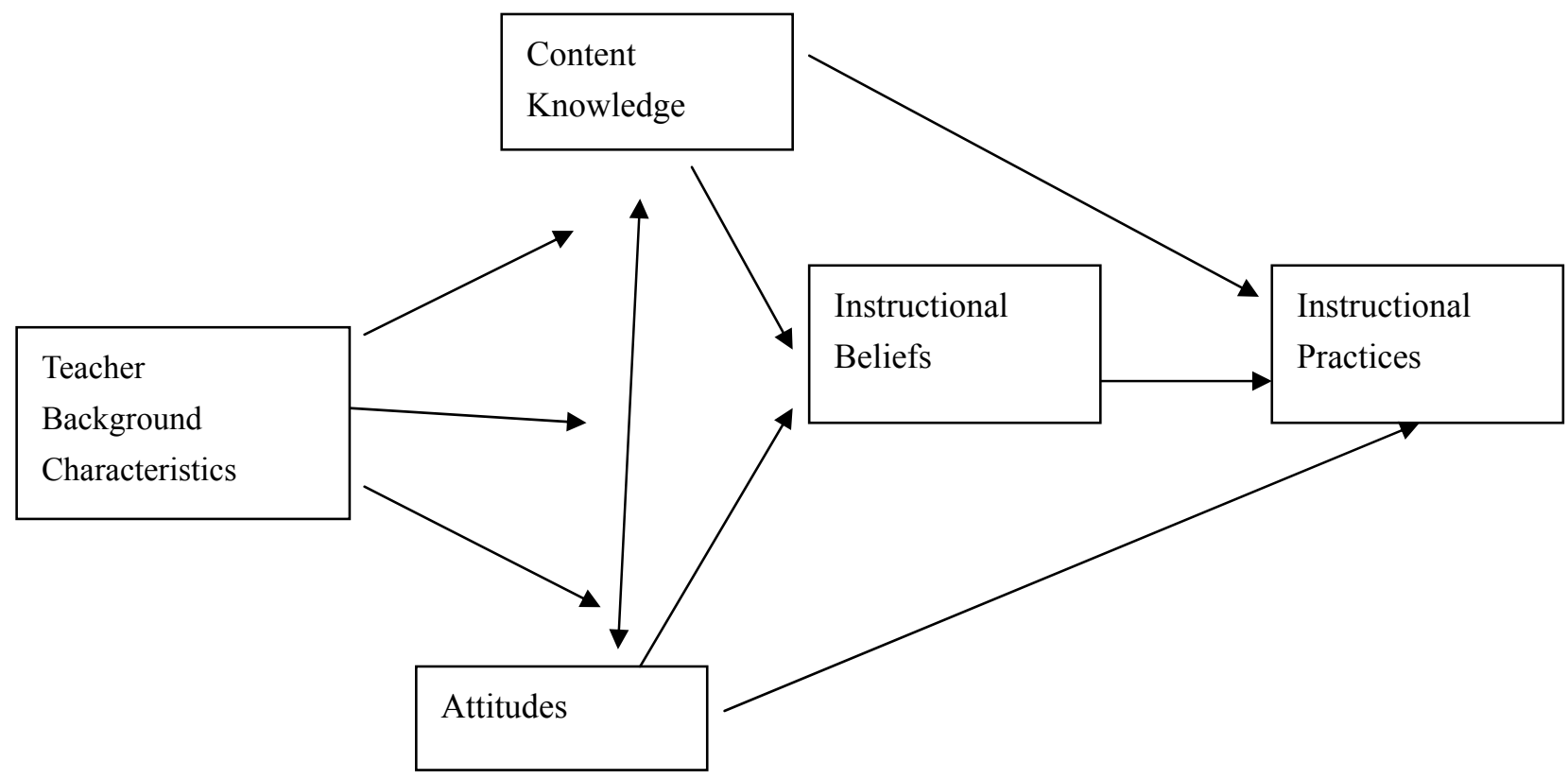

Figure 1. Theoretical Model Relating Teachers' Content Knowledge, Attitudes, Instructional Beliefs, and Instructional Practices (Earnest, 1989) 


\subsection{Performance in Mathematics}

Educators and researchers have attributed many reasons for students' performance in mathematics: level of instruction and teacher competency (Khan, 2008), learners mathematical ability and genetics (Gilroy, 2002), problems such as math anxiety, math phobia, math avoidance, gender differences (Tocci \& Engelhart, 1991), socio-economic status (Kainuwa \& Yusuf, 2013) and math beliefs, emotions and attitude (Fennema \& Sherman, 1976; Maasz and Schloglmann, 2009; Wilkins, 2008). However, teaching is often associated content knowledge and pedagogy (Shulman, 1986) but learners do best when they achieve conceptual understanding of mathematical concepts (Singh, Granville, \& Dika, 2002).

Maasz and Schloglmann (2009) concluded that "prospective teachers undertaking university education bring with them beliefs and attitudes toward teaching acquired during their years as students at school and these beliefs can be barriers to developing new teacher competencies" (p.9). Definitions of attitudes related to mathematics abound. But there are common elements to all definitions. The social construct attitude is "influenced by many factors like gender social strata, age, stream of education and previous experience of the job" (Bhargava, 2014, p.27). Whether attitude is positive or negative, it is conclusively linked to emotions, beliefs, behavior and values (DeBellis, V. \& Goldin, G.A.1999; Zan \& Martino, 2008).

There has been evidence that teachers, including pre-teachers, beliefs and attitudes highly influence the way they teach (Furinghetti \& Pehkonen, 2000; Philipp, 2007; Zevenbergen, 2005). Nevertheless, some pre-service teachers with low mathematics content knowledge display beliefs and attitudes consistent with their more capable colleagues. Hence, there are always concerns about quality mathematics teacher competence in the classroom (Lowrie \& Jorgensen, 2015).

\subsection{Math Attitudes}

Within the last two decades, researchers have concluded that success in mathematics involves affective variables such as student ability, perceptions, parent and peer influences, socioeconomic factors and attitudes (Uysal \& Yuksel, 2016). Ercilean, McCreith, \& Lapointe (2005) stated that students' attitude to mathematics was one of the strongest predictors of mathematics achievement. However, the jury is still out on the verdict around the relationship between math attitude and math achievement. Some researchers have suggested that attitude influences achievement (Reynolds \& Walberg, 1992) while others have argued that achievement influences attitude (Imai, 1993).

The significance of positive attitudes in general, and towards mathematics in particular is invaluable to teacher educators so that they can provide high levels of instruction to their students. Poor attitudes towards mathematics result in poor conceptual understanding of mathematical content as well as inability to provide quality pedagogy (Schuck \& Grotenboer, 2004).

Research on attitudes in mathematics in teacher education (Aldridge \& Bobis, 2001; Grootenboer, 2003b; Grootenboer \& Lowrie, 2002; White, Perry, Way \& Southwell, 2006) reported a significant number of negative attitudes among these teachers. However, there is a dearth of research on Caribbean student teachers' attitudes towards learning and teaching mathematics. Tertiary educators continue to face the dilemma created by the demonstration of many negative attitudes and beliefs towards mathematics by trainee teachers. Poor mathematics students would mean poor mathematics teachers and vice versa.

This paper examines student teachers' attitudes towards mathematics learning and teaching. Concerns were initiated when student teachers (in-service and pre-service), who were enrolled in a mathematics methods course at the national university in Trinidad and Tobago expressed concerns, fears, doubts and anxiety about their ability as students and teachers of mathematics. Applicants must be successful at the Caribbean Examination Council's (CXC) Caribbean Secondary Education Certificate (CSEC) Mathematics before being accepted in the Centre for Education Programmes.

\subsection{Research Questions}

This paper is guided by the following research questions:

1) Do the attitudes towards mathematics of student teachers, influence their teaching competence?

2) What factors contribute to positive student teachers' attitudes towards mathematics and teaching mathematics? 


\section{Methodology}

\subsection{Research Model}

Based on the data collected, a model of four main factors was proposed. Presumably these factors influence the student's attitude towards Math learning and teaching. The proposed model was:

$\mathrm{Y}_{\text {Maths Attitude }}=\alpha+\mathrm{F}_{\text {feelings }}+\mathrm{E}_{\text {Expectations }}+\mathrm{U}_{\text {Usefulness }}+\mathrm{G}_{\text {Gender }}+\varepsilon$

Each main factor (Model 1) was surveyed in further detailed into several sub-factors or variables that are listed under each analysis (Models 2 to 5).

\subsection{Participants}

The sample comprised 165 Years 3 and 4 fulltime and part-time student teachers who were pursuing a four year Bachelor of Education degree programme at the University of Trinidad and Tobago. The purposive sample was select from students who had pursued courses in Mathematics at the university and expressed concerns about their knowledge and teaching competence of the subject. The senior researcher teaches two Year 3 undergraduate mathematics courses. All trainee primary school teachers are required to teach mathematics at elementary school as part of their mandatory practicum course requirements in preparation for becoming teachers. All participants had completed at least two mandatory primary education mathematics content and methods courses at the university.

\subsection{Data Collection Instrument}

Participants completed the 20 minute Mathematics Attitude Survey which was adapted from the Fennema-Sherman (1986) mathematics attitude scale into a 13 item survey. The first six items requested general demographic information. Items 7-10 comprised items based on a 5 point Likert scale which required student teachers to respond Strongly Agree, Agree, Undecided, Disagree or Strongly Disagree $(1=$ Strongly Disagree to $5=$ Strongly Agree $)$. These items requested information on feelings about mathematics as an academic subject, expectations about mathematics, usefulness of mathematics and perceived gender influences on mathematics. Questions 11 to 13 required qualitative responses about the student teachers' past and present mathematical experiences and feelings.

\section{Data Collection and Analysis}

The analysis was conducted using the MINTAB Statistical package. The data were initially analyzed to compute percentage respondents for each factor. These are presented in tables 3- 4.

Table 2: Equations for variables

Y Math attitude $=\boldsymbol{\alpha}+\mathbf{F}_{\text {feelings }}+\mathbf{E}_{\text {Expectations }}+\mathbf{U}_{\text {Usefulness }}+\mathbf{G}_{\text {Gender }}+\boldsymbol{\varepsilon}$ :

$\mathbf{Y}_{\text {Feelings }}=\alpha+\mathbf{S b}+\mathbf{M x}+\mathbf{M c}+\mathbf{M c}+\mathbf{M u}+\mathbf{T g}+\mathbf{L m}+\mathbf{H m}+\mathbf{T i}+\mathbf{G c}+\mathbf{C m}+\mathbf{M g}+\mathbf{P S}+\varepsilon$ :

$\mathbf{Y}_{\text {usefulness }}=\alpha+\mathrm{Ca}+\mathrm{NE}+\mathbf{A d}+\mathbf{U e}+\mathbf{V p}+\mathbf{D u}+\mathbf{W t}+\mathbf{N u}+\mathbf{S m}+\varepsilon$ :

$\mathbf{Y}_{\text {Expectations }}=\alpha+\mathbf{C u}+\mathbf{G b}+\mathbf{G g}+\mathbf{S L}+\mathbf{C x}+\mathbf{T h}+\mathbf{N w 1}+\mathbf{O p}+\mathbf{N w}+\varepsilon:$

$\mathbf{Y}_{\text {Gender }}=\boldsymbol{\alpha}+\mathbf{M b}+\mathbf{F g}+\mathbf{W s}+\mathbf{F p}+\mathbf{A m}+\mathbf{W p}+\varepsilon:$

Model 5

The data were then analyzed using the generalized linear model (GLIM) and the best fit equations reported. Regression analysis was conducted with the independent variable as the "degree of Agree" and is represented in the equations as. The dependent variable [ $[\mathrm{Y}]$ was the response for each factor from the survey, and is computed as a percentage. The Fennema-Sherman (1986) mathematics Attitude scale was adapted to formulate a 13 item survey in this study. The scale is divided into four subscales basically feelings, expectations, usefulness and gender. Table 3 shows the respondent feelings on Agree and Disagree response in percentage.

\section{Findings}

The analysis using GLIM revealed that the sub factors or variables presented in Model 2 to 5 were significant. When more than $60 \%$ of a variable were significant, as Strongly Agreed, then it was accepted. Similarly, when more than $60 \%$ of a variable were significant, as Strongly Disagree, then that value was accepted and considered significant to the proposed Model 1. 
Table 3. Feelings about Mathematics

\begin{tabular}{|c|c|c|c|}
\hline 8 & 52.12 & Disagree & Math is my best subject \\
\hline 2 & 53.94 & & Mathematics is hard for me \\
\hline 12 & 57.58 & & I never gained a conceptual understanding of math \\
\hline 9 & 63.03 & & Math is not for me \\
\hline 10 & 64.24 & & Math confuses me \\
\hline 11 & 84.24 & & Math is less important than language and art \\
\hline 5 & 51.52 & Agree & I feel confident when I do math \\
\hline 14 & 58.18 & & I get good grades in mathematics \\
\hline 16 & 58.18 & & I learn math better when I work with another person or a group \\
\hline 1 & 59.39 & & I love mathematics \\
\hline 19 & 61.82 & & Math labs promote math understanding \\
\hline 17 & 63.64 & & I learn math best using manipulatives and technology \\
\hline 15 & 65.45 & & I am persistent in solving math problems. Math is a worthwhile, necessary subject \\
\hline 4 & 70.91 & & I get good grades in math \\
\hline 18 & 84.85 & & Mathematics has its own language \\
\hline
\end{tabular}

The Factors on Feelings about Mathematics "Best subject, Math not for me, Math confuses, and Math important "(Table 3, Figure 4) displayed a positive quadratic response.

The question "math is less important than language and art" received $84.24 \%$ disagree indicating the feelings of the respondents about the importance of math. The lowest response $52.12 \%$ went to the question, "Math is my best subject." This meant that more persons felt that math is not their favorite subject and that they have preferred subjects. On the other hand the statement "math has its own language" earned the Agree score of 84.85\%, whereas "I feel confident when I do math" had the lowest Agree score of 51.52\% indicating some measure of math phobia. This is a signal that respondents have less confidence in their capability of doing math. It can also reflect on their competence as math teachers.

Table 4. Feelings about Mathematics

\begin{tabular}{lllll}
\hline Factor & Code & Regression & $\mathrm{R}^{2}$ & Equation \\
\hline Best subject & $\mathrm{Sb}$ & $\mathrm{T}_{\mathrm{Sb}}=29.2+13.9 \mathrm{~A}-3.50 \mathrm{~A}^{2}$ & 83.1 & 1.1 \\
Math not for me & $\mathrm{Mx}$ & $\mathrm{Y}_{\mathrm{Mx}}=57.8-4.5 \mathrm{~A}-1.07 \mathrm{~A}^{2}$ & 82.1 & 1.2 \\
Math confuses & $\mathrm{Mc}$ & $\mathrm{Y}_{\mathrm{Mc}}=52.8-0.3 \mathrm{~A}-1.71 \mathrm{~A}^{2}$ & 69.5 & 21.3 \\
Math important & $\mathrm{Mp}$ & $\mathrm{Y}_{\mathrm{Mp}}=123-47.6 \mathrm{~A}+4.79 \mathrm{~A}^{2}$ & 86.2 & 1.4 \\
Math understanding & $\mathrm{Mu}$ & $\mathrm{Y}_{\mathrm{Mu}}=40.6+6.3 \mathrm{~A}-2.50 \mathrm{~A}^{2}$ & 77.8 & 1.5 \\
Good teachers & $\mathrm{Tg}$ & $\mathrm{Y}_{\mathrm{Tg}}=-21.8+40.8 \mathrm{~A}-6.21 \mathrm{~A}^{2}$ & 68.2 & 1.6 \\
Love maths & $\mathrm{Lm}$ & $\mathrm{Y}_{\mathrm{Lm}}=-26.2+36.8 \mathrm{~A}-4.64 \mathrm{~A}^{2}$ & 71.5 & 1.7 \\
Maths hard & $\mathrm{Hm}$ & $\mathrm{Y}_{\mathrm{Hm}}=1.4+35.4 \mathrm{~A}-6.79 \mathrm{~A}^{2}$ & 49.3 & 1.8 \\
Teacher interest & $\mathrm{Ti}$ & $\mathrm{Y}_{\mathrm{TI}}=-34.2+49.2 \mathrm{~A}-7.36 \mathrm{~A}^{2}$ & 90.8 & 1.9 \\
Good grades & $\mathrm{Gg}$ & $\mathrm{Y}_{\mathrm{Gg}}=-45.2+48.1 \mathrm{~A}-6.07 \mathrm{~A}^{2}$ & 44.5 & 1.10 \\
Confident in math & $\mathrm{Cm}$ & $\mathrm{Y}_{\mathrm{Cm}}=-42.4+54.9 \mathrm{~A}-8.14 \mathrm{~A}^{2}$ & 74.8 & 1.11 \\
Good grades & $\mathrm{Mg}$ & $\mathrm{Y}_{\mathrm{Mg}}=0.40+24.2 \mathrm{~A}-3.64 \mathrm{~A}^{2}$ & 83 & 1.12 \\
Persistent solving & $\mathrm{Ps}$ & $\mathrm{Y}_{\mathrm{Ps}}=-34.4+39.8 \mathrm{~A}-4.79 \mathrm{~A}^{2}$ & 59 & 1.13 \\
Learn person & $\mathrm{Lp}$ & $\mathrm{Y}_{\mathrm{Lp}}=-38.2+46.4 \mathrm{~A}-6.21 \mathrm{~A}^{2}$ & 74 & 1.14 \\
Learn technology & $\mathrm{Lt}$ & $\mathrm{Y}_{\mathrm{Lt}}=-46.4+49.3 \mathrm{~A}-6.29 \mathrm{~A}^{2}$ & 68 & 1.15 \\
Maths lang & $\mathrm{Mi}$ & $\mathrm{Y}_{\mathrm{Ml}}=-8.4+5.3 \mathrm{~A}+2.29 \mathrm{~A}^{2}$ & 77.6 & 1.16 \\
Labs understanding & $\mathrm{Lv}$ & $\mathrm{Y}_{\mathrm{Lv}}=-62.8+61.7 \mathrm{~A}-8.14 \mathrm{~A}^{2}$ & 69.6 & 1.17 \\
\hline
\end{tabular}




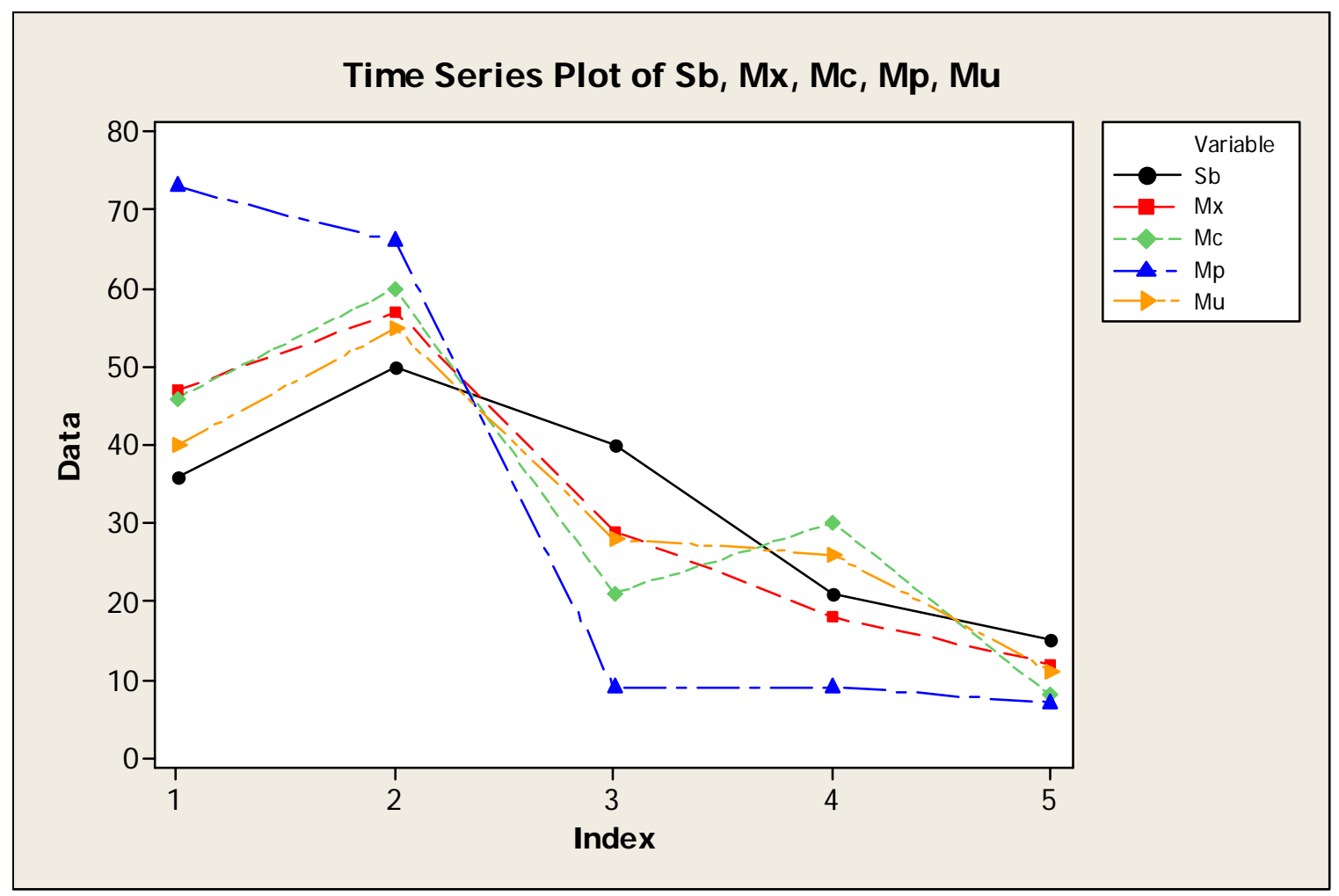

Figure 2a. Feelings about Mathematics

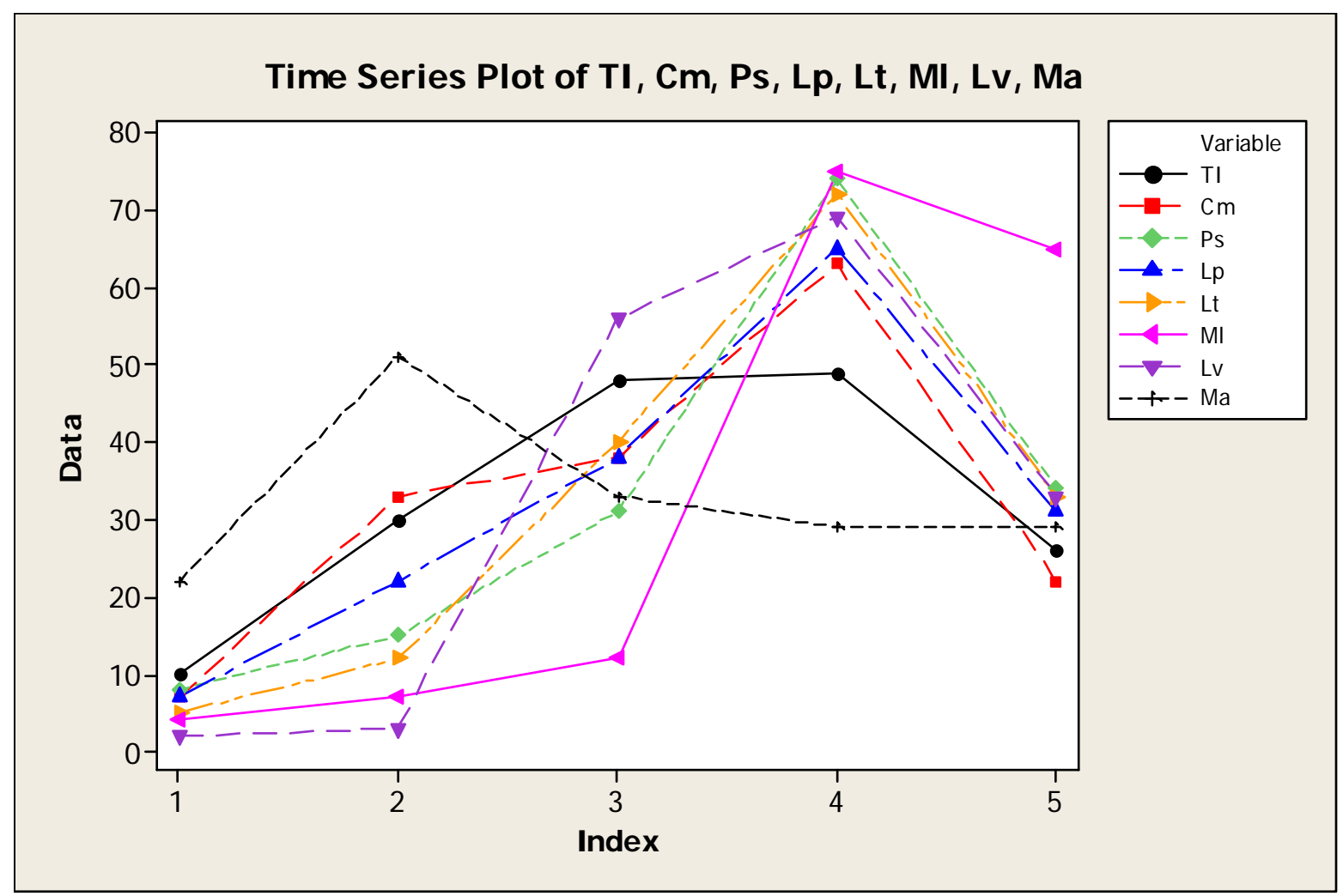

Figure 2b. Feelings about Mathematics 


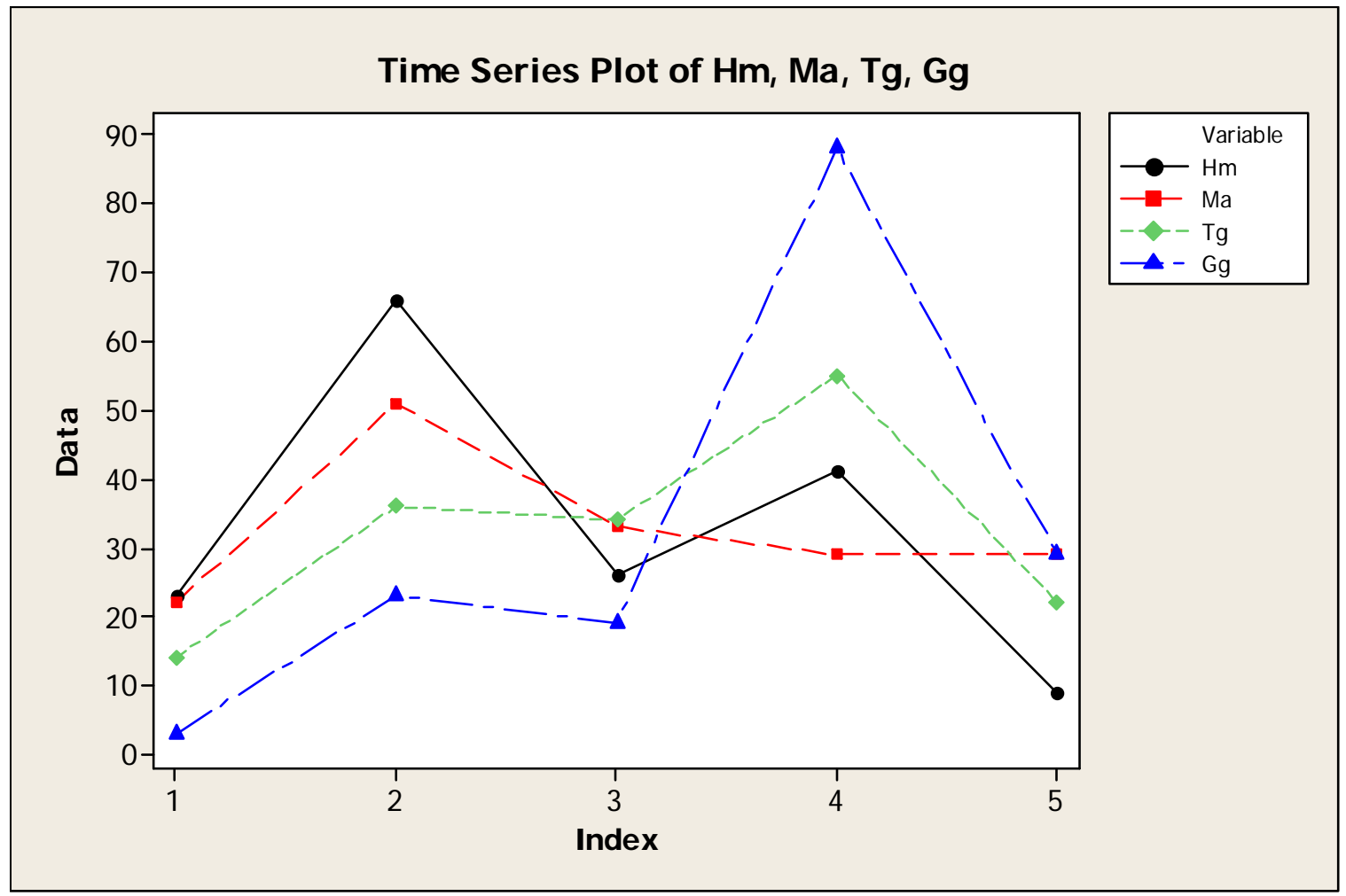

Figure 2c. Feelings about Mathematics

\subsection{Usefulness of Mathematics}

The survey on the usefulness of mathematics covered a wide range of which five (5) of the issues evoked positive quadratic responses (Table 2) as it was found to improve students' career and assisted them in the routine tasks. The subscale for the Usefulness of Math Table 5 gave a high Disagree score of the question "taking math is a waste of time $92.73 \%$ " which is a clear emphasis of the teachers' concept of the usefulness of math in people's lives. Positive attitudes towards math can be deduced from this subscale.

Table 5. Usefulness of Mathematics

\begin{tabular}{llll}
\hline 6 & 57.58 & Disagree & I can survive with minimum math knowledge \\
5 & 78.18 & & I would not use mathematics very often after school \\
3 & 92.73 & & Taking math is a waste of time \\
\hline 1 & 82.42 & Agree & Mathematics will improve my career chances \\
7 & 90.91 & & Mathematics is used in almost everything \\
8 & 90.91 & Mathematics is vital for progress \\
2 & 92.73 & Mathematics is a worthwhile, necessary subject \\
9 & 93.94 & Mathematics is used in daily tasks \\
4 & 95.15 & Mathematics can be useful in adult life \\
\hline
\end{tabular}

The question "I can survive with a minimum math knowledge had 57.58\%" is also supportive of the usage of math's. In the Agree category the highest score was recorded for the question "Math can be useful in adult life (95.15\%)" affirming the usefulness of math by the great majority of adults. Four other questions of Math usefulness in daily tasks, being a necessary subject, vital for progress and used in everyday life received more than $90 \%$ agreement. 
The results indicate that for most of the participants, there is a synergy with usefulness and necessity for math in their career development and it was essential for their progress. Less than $10 \%$ of the participants found that math was not useful and three (3) of the variables (Figure 3b) exhibited a negative quadratic response (Table 6, Equations 3.7 to 3.9), thus affirming the usefulness of math by adults.

Table 6. Usefulness of Mathematics

\begin{tabular}{lllll}
\hline Factor & code & Regression & $\mathrm{R}^{2}$ & Equation \\
\hline Career & $\mathrm{Ca}$ & $\mathrm{Y}_{\mathrm{Ca}}=-11.1+10.9 \mathrm{~A}+0.41 \mathrm{~A}^{2}$ & 80.9 & 3.1 \\
Necessary & $\mathrm{Ne}$ & $\mathrm{Y}_{\mathrm{Ne}}=1.1-3.2 \mathrm{~A}+3.13 \mathrm{~A}^{2}$ & 83.6 & 3.2 \\
Adult & $\mathrm{Ad}$ & $\mathrm{Y}_{\mathrm{Ad}}=3.6-8.7 \mathrm{~A}+4.29 \mathrm{~A}^{2}$ & 85.1 & 3.3 \\
Used everything & $\mathrm{Ue}$ & $\mathrm{Y}_{\mathrm{Ue}}=-3.3+0.2 \mathrm{~A}+2.56 \mathrm{~A}^{2}$ & 89.4 & 3.4 \\
Vital progress & $\mathrm{VP}$ & $\mathrm{Y}_{\mathrm{Vp}}=-17.1+13.3 \mathrm{~A}+0.27 \mathrm{~A}^{2}$ & 78.0 & 3.5 \\
Daily use & $\mathrm{Du}$ & $\mathrm{Y}_{\mathrm{Du}}=-5.8+2.1 \mathrm{~A}+2.29 \mathrm{~A}^{2}$ & 78.5 & 3.6 \\
Waste & $\mathrm{Wt}$ & $\mathrm{Y}_{\mathrm{Wt}}=114-49.5 \mathrm{~A}+5.48 \mathrm{~A}^{2}$ & 95.2 & 3.7 \\
Not use & $\mathrm{Nu}$ & $\mathrm{Y}_{\mathrm{Nu}}=76.8-22.1 \mathrm{~A}+1.46 \mathrm{~A}^{2}$ & 96.7 & 3.8 \\
Survive & $\mathrm{Sm}$ & $\mathrm{Y}_{\mathrm{Sm}}=29.1+8.8 \mathrm{~A}-2.52 \mathrm{~A}^{2}$ & 84.4 & 3.9 \\
\hline
\end{tabular}

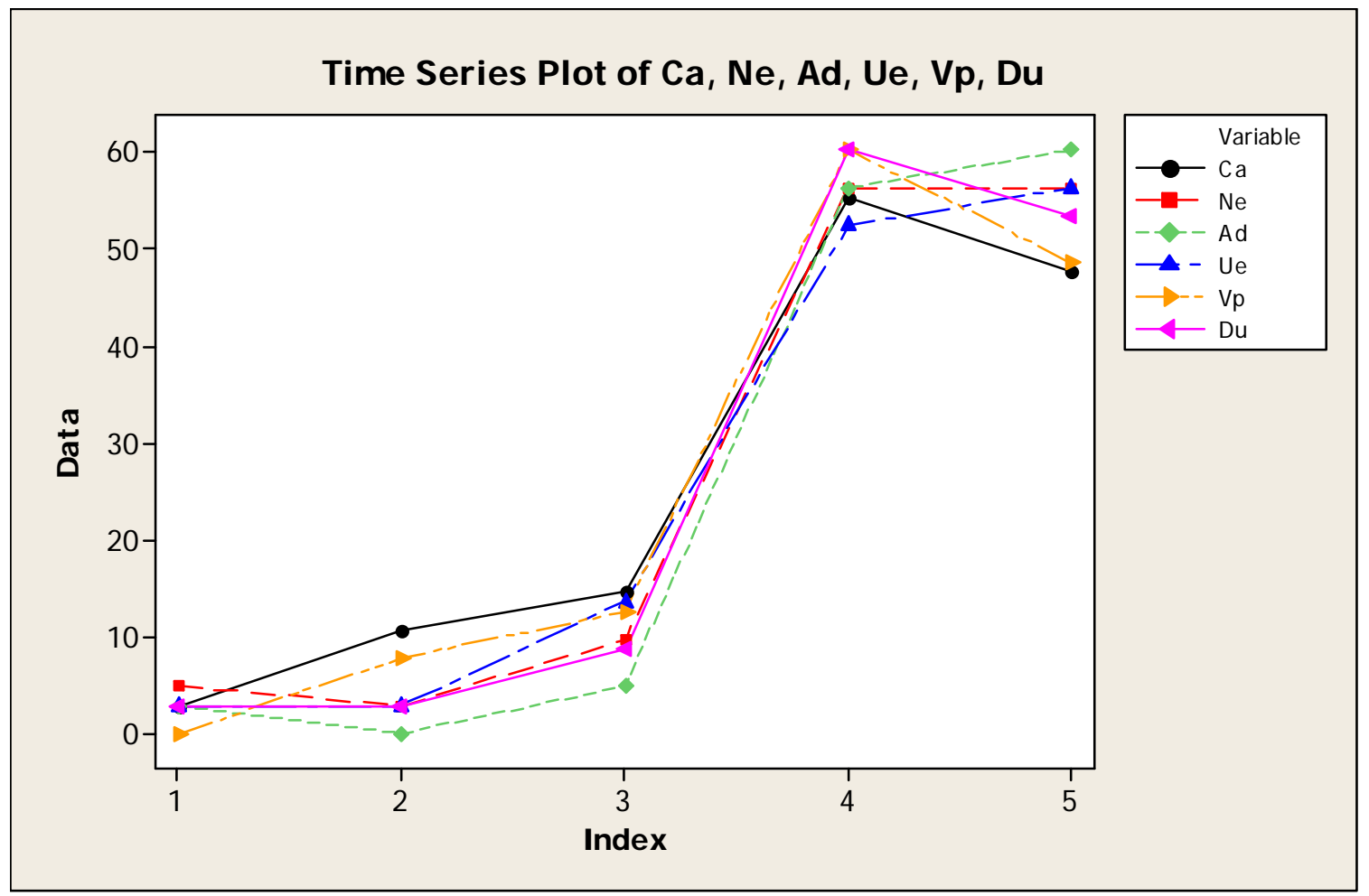

Figure 2d. Usefulness of Mathematics 


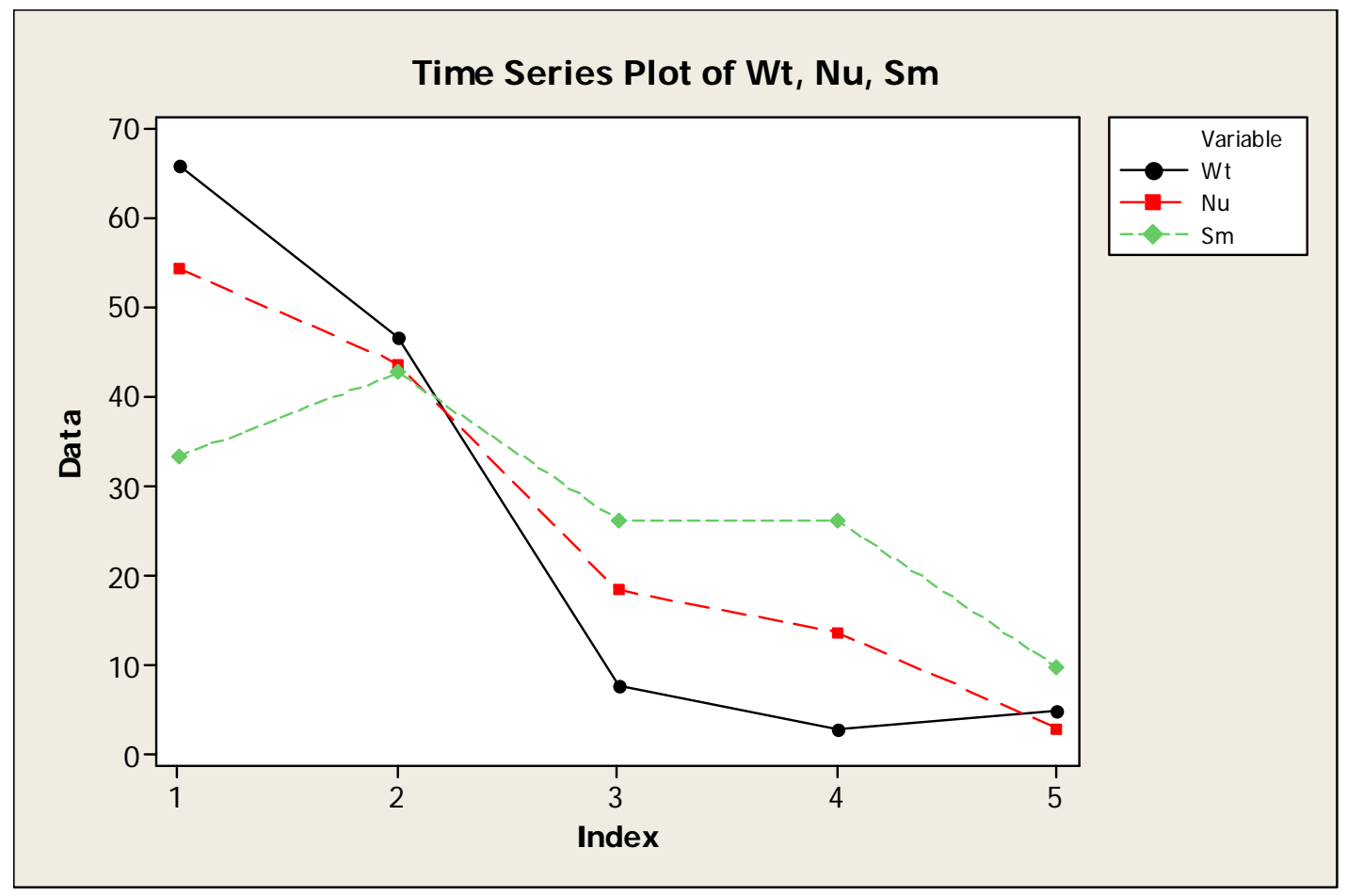

Figure 2e. Usefulness of Mathematics

\subsection{Mathematics Expectations}

The Expectations of students for mathematics (Table 7) showed a high Disagree score of (79.39\%) for the question "I will never do math well" indicating that the majority of respondents expect themselves to perform well in mathematics. This had a negative quadratic response together with "hopeless". This question, "Ordinary students do not do math well" scored (62.42\%) Disagree which means they are expected to do well in mathematics.

Table 7. Expectations of Students for Mathematics

\begin{tabular}{llll}
\hline 8 & 62.42 & Disagree & Ordinary students do not do math well \\
6 & 66.67 & & My teachers thought I was hopeless at math \\
3 & 76.36 & I will never do math well \\
7 & 79.39 & I will never do math well \\
\hline 9 & 55.76 & Agree & I hope to study a lot more math \\
2 & 71.52 & & I am getting better at math \\
4 & 75.76 & I expect good grades in math \\
5 & 76.97 & I know I can excel in math \\
1 & 79.39 & I need a conceptual understanding of math \\
\hline
\end{tabular}

The factors "Conceptual understanding, Getting better, Good grades, Study a lot, and Can Excel" exhibited a positive quadratic response (Table 8 and Figure 3a). The question "I need a conceptual understanding of math" (79.37\%) gives a clear indication that the majority of the respondents have a problem of conceiving mathematical concepts. The lowest score $55.76 \%$, in the Agree category was for the question "I hope to study a lot more math". This is another expectation that persons could change their attitude by studying more math. Two questions received high scores "I know I can excel in math 76.97\%" and "I expect good grades in math 75.76\%" a strong expectation that changes the attitude towards math. 
Table 8. Mathematics Expectations

\begin{tabular}{lllll}
\hline Factor & $\mathrm{Code}$ & regression & $\mathrm{R}^{2}$ & Equation \\
\hline Conceptual understanding & $\mathrm{Cu}$ & $\mathrm{Y}_{\mathrm{Cu}}=1.7+6.4 \mathrm{~A}+0.54 \mathrm{~A}^{2}$ & 65.1 & 2.1 \\
Getting better & $\mathrm{Gb}$ & $\mathrm{Y}_{\mathrm{Gb}}=-33.8+36.5 \mathrm{~A}-4.44 \mathrm{~A}^{2}$ & 73.5 & 2.2 \\
Good grades & $\mathrm{Gg}$ & $\mathrm{Y}_{\mathrm{Gg}}=-25.9+26.7 \mathrm{~A}-2.51 \mathrm{~A}^{2}$ & 70.6 & 2.3 \\
Study lot & $\mathrm{SL}$ & $\mathrm{Y}_{\mathrm{Sl}}=-27.6+38.4 \mathrm{~A}-5.47 \mathrm{~A}^{2}$ & 58.5 & 2.4 \\
Can Excel & $\mathrm{Cx}$ & $\mathrm{Y}_{\mathrm{Cx}}=-30.6+34.6 \mathrm{~A}-4.87 \mathrm{~A}^{2}$ & 47.7 & 2.5 \\
Though hopeless & $\mathrm{Th}$ & $\mathrm{Y}_{\mathrm{Th}}=57.6-11.2 \mathrm{~A}+0.279 \mathrm{~A}^{2}$ & 97 & 2.6 \\
Never do math well & $\mathrm{Nw} 1$ & $\mathrm{Y}_{\mathrm{Nw} 1}=77.9-22.3 \mathrm{~A}+1.38 \mathrm{~A}^{2}$ & 97 & 2.7 \\
Ordinary & $\mathrm{Op}$ & $\mathrm{Y}_{\mathrm{Op}}=28.2+11.7 \mathrm{~A}-3.26 \mathrm{~A}^{2}$ & 92.6 & 2.8 \\
Never do math & $\mathrm{Nw}$ & $\mathrm{Y}_{\mathrm{Nw}}=75.6-21.4 \mathrm{~A}+1.39 \mathrm{~A}^{2}$ & 98 & 2.9 \\
\hline
\end{tabular}

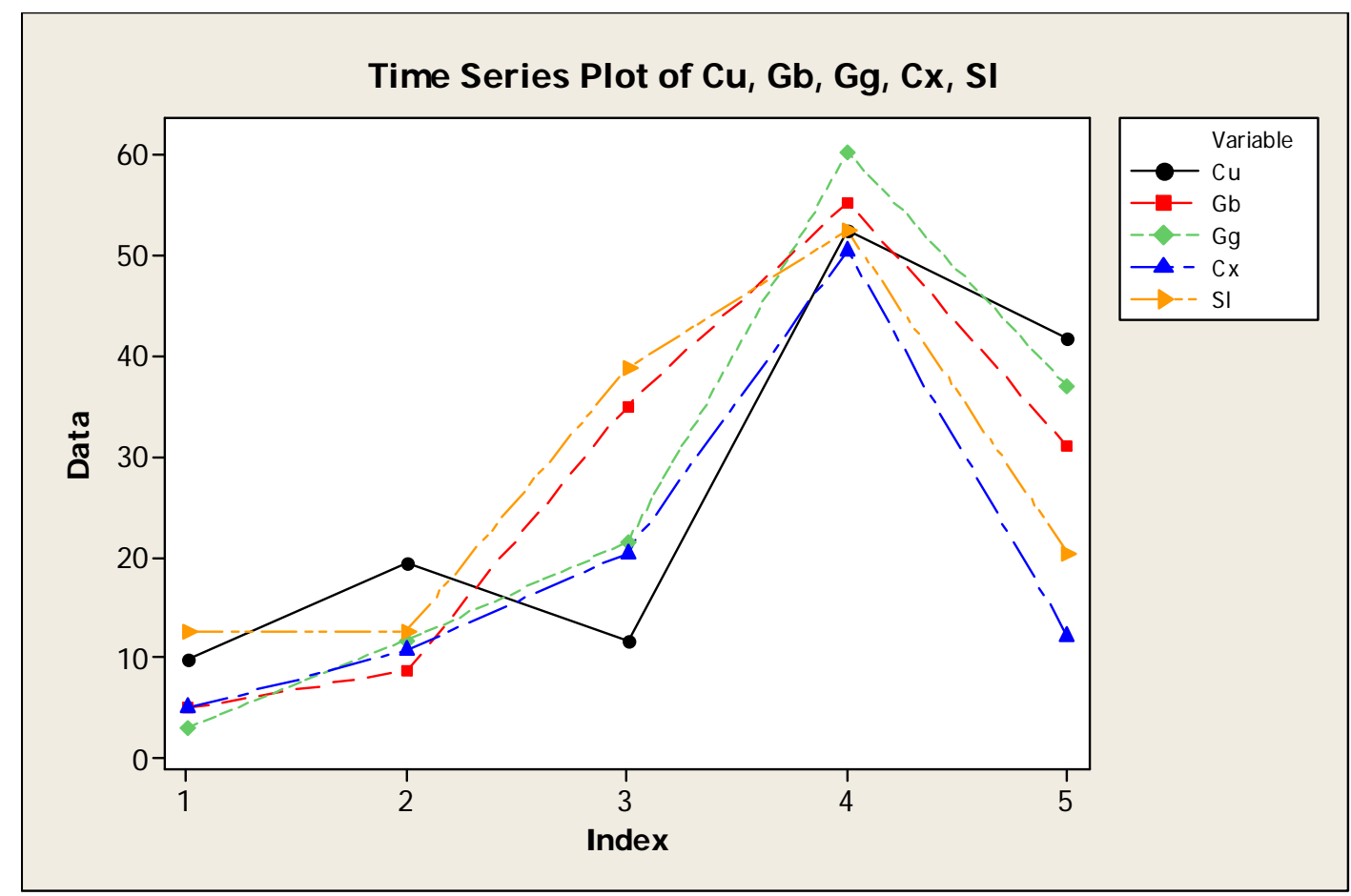

Figure 3a. Mathematics Expectations 




Figure 3b. Mathematics Expectations

\subsection{Gender and Mathematics}

The factors "Males better, Females not genius, Women strange, and Faith male" exhibited a similar negative quadratic response, suggesting more people believe it is true (Table 9, Figure 10). One question in the Agree category "Woman can do just as well as men in math" scored 85.45 \% (Table 9) a strong statement that gender is not a determining factor for excelling in math (Mohamed \& Waheed, 2011).

Table 9. Gender and Mathematics

\begin{tabular}{llll}
\hline 1 & 54.55 & Disagree & Males are better at math than females \\
\hline 6 & 58.79 & & I have more in a male math teacher \\
5 & 80.00 & & Women who like math are strange \\
2 & 86.06 & & A female cannot be a genius at math \\
3 & 85.45 & Agree & Woman can do just as well as men in math \\
\hline
\end{tabular}

However, on the question "A female cannot be a genius at math" (86.6\% Disagree) suggests that gender cannot be counted as a determining factor for being a genius in math.

Table 10. Gender and Mathematics

\begin{tabular}{lllll}
\hline Factor & code & regression & $\mathrm{R}^{2}$ & Equation \\
\hline Males better & $\mathrm{Mb}$ & $\mathrm{Y}_{\mathrm{Mb}}=7.80+22.9 \mathrm{~A}-4.44 \mathrm{~A}^{2}$ & 81.8 & 4.1 \\
Females not genius & $\mathrm{Fg}$ & $\mathrm{Y}_{\mathrm{Fg}}=112-50.0 \mathrm{~A}+5.84 \mathrm{~A}^{2}$ & 92.3 & 4.2 \\
Women strange & $\mathrm{Ws}$ & $\mathrm{Y}_{\mathrm{Ws}}=73.6-21.2 \mathrm{~A}+1.52 \mathrm{~A}^{2}$ & 86.6 & 4.3 \\
Faith male & $\mathrm{Fm}$ & $\mathrm{Y}_{\mathrm{Fm}}=37.1+1.5 \mathrm{~A}-1.25 \mathrm{~A}^{2}$ & 63.4 & 4.4 \\
Women math & $\mathrm{Wm}$ & $\mathrm{Y}_{\mathrm{Wm}}=16.8-14.2 \mathrm{~A}+4.73 \mathrm{~A}^{2}$ & 94.1 & 4.5 \\
Females persistent & $\mathrm{Fp}$ & $\mathrm{Y}_{\mathrm{Fp}}=-40.8+52.3 \mathrm{~A}-8.11 \mathrm{~A}^{2}$ & 62 & 4.6 \\
Advance maths & $\mathrm{Am}$ & $\mathrm{Y}_{\mathrm{Am}}=-34.8+49.1 \mathrm{~A}-7.77 \mathrm{~A}^{2}$ & 59.9 & 4.7 \\
Women problem solvers & $\mathrm{Wp}$ & $\mathrm{Y}_{\mathrm{Wp}}=-21.4+37.6 \mathrm{~A}-5.81 \mathrm{~A}^{2}$ & 60.4 & 4.8 \\
\hline
\end{tabular}




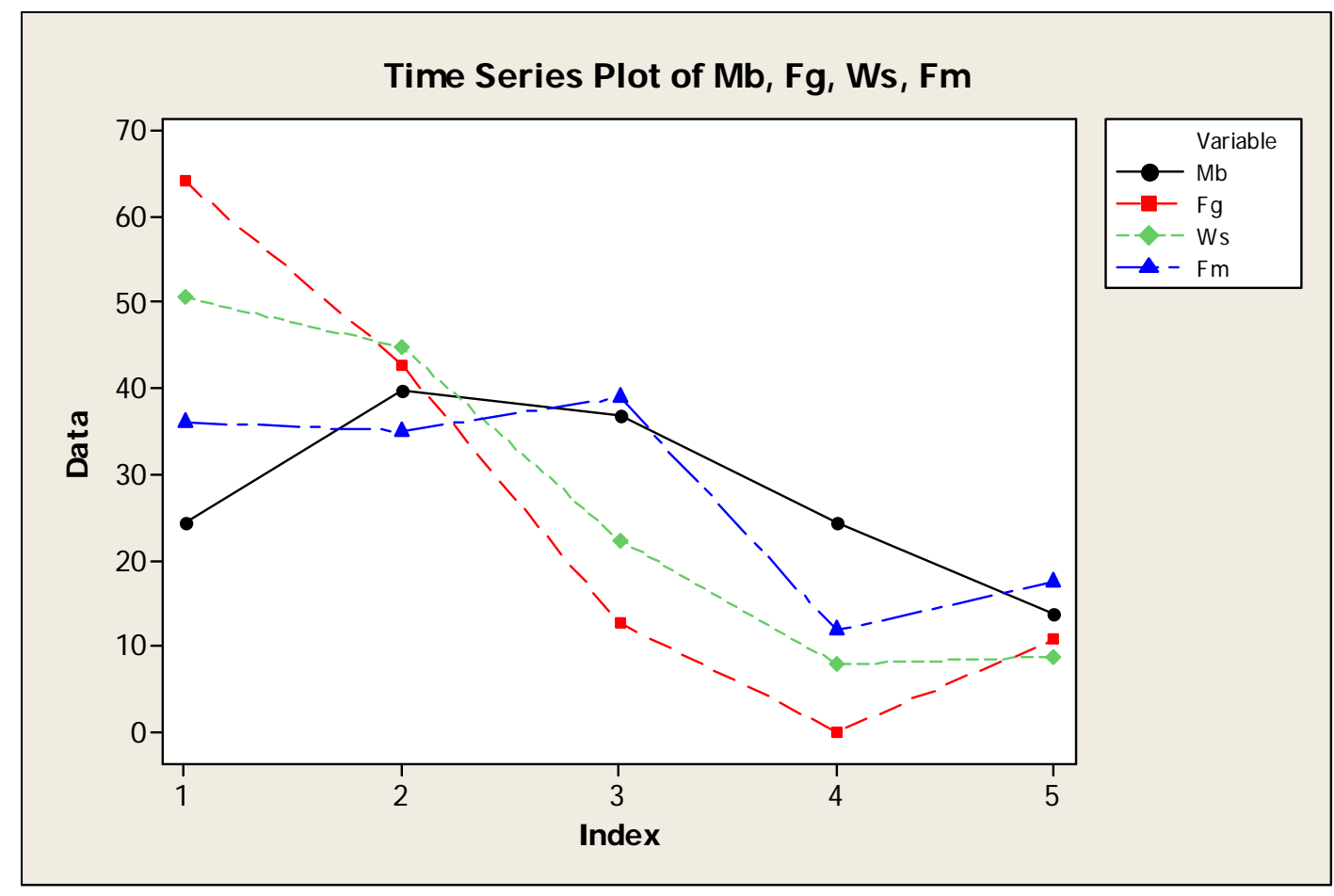

Figure 3c. Gender and Mathematics

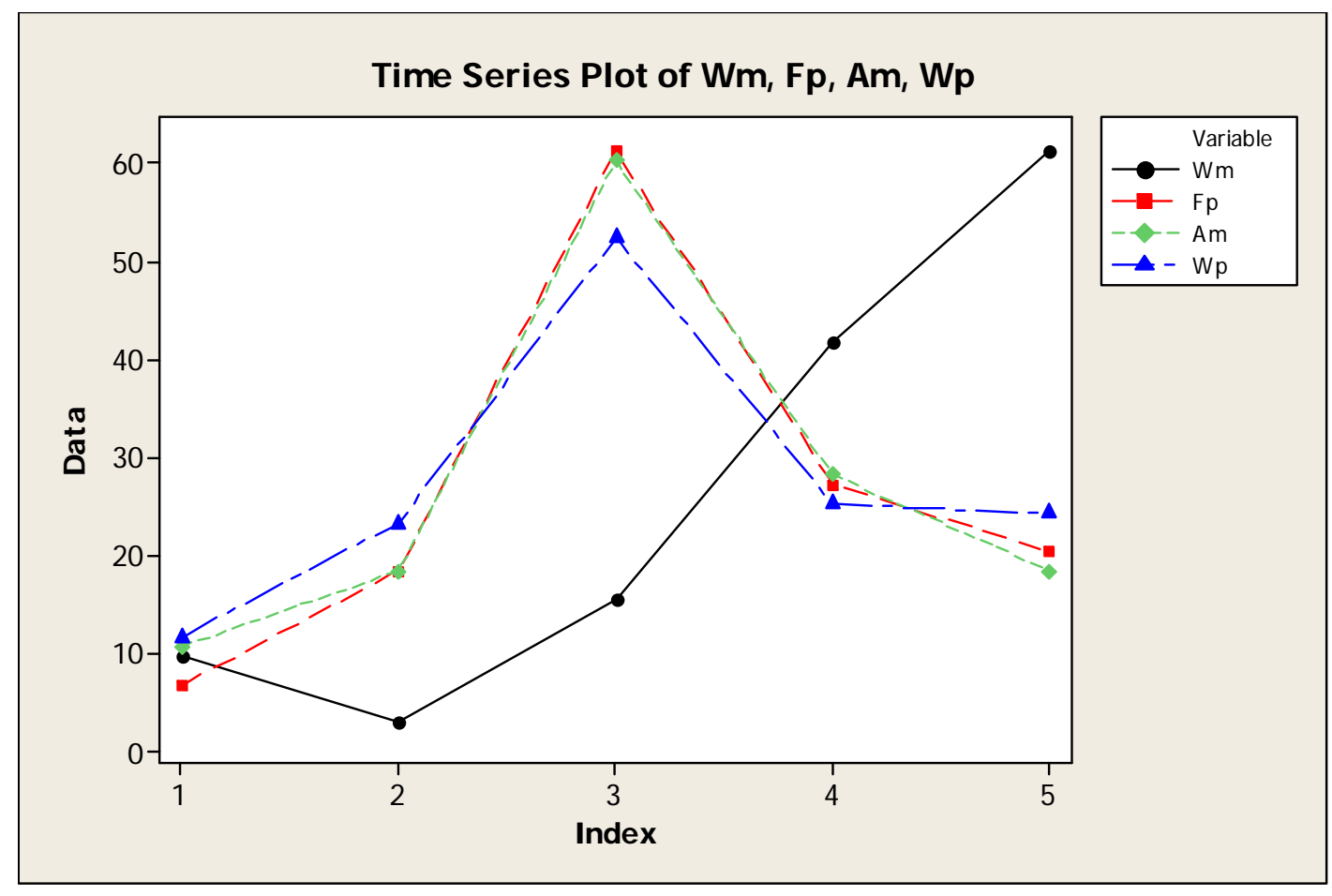

Figure 3c. Gender and Mathematics 


\section{Conclusion and Recommendations}

It can be said that the proposed Model 1:

$\mathrm{Y}_{\text {Maths Attitude }}=\alpha+\mathrm{F}_{\text {feelings }}+\mathrm{E}_{\text {Expectations }}+\mathrm{U}_{\text {Usefulness }}+\mathrm{G}_{\text {Gender }}+\varepsilon$ : was positive in determining student attitudes toward math in three subscales. These are Feelings, Expectations and Usefulness. The subscale Gender proved to be a negative factor in determining students' attitude towards math. In their teaching competence students are governed or driven by these three factors. With strong feelings and high expectations student teachers are capable of performing to their optimum in teaching math. The usefulness of mathematics in their career and public life is another driving factor that could enhance their performance as math teachers irrespective of their gender.

Mathematics instruction at elementary and high schools should equip students with conceptual understanding of mathematical concepts and authentic applications to provide early positive feelings and attitudes towards mathematics. Teacher education programmes should provide pedagogical training to trainee teachers who have negative attitudes towards mathematics. Training should be mandatory to improve conceptual and pedagogical knowledge, provide enjoyment (Curtis, 2006), and hence beliefs and positive attitudes. How we learn is usually not how we should teach.

Dembo (2001) concluded that "Pre-service education should have two complementary goals. First, it should teach future teachers to become more effective learners themselves and secondly, it should teach them to be more effective teachers" (p.10). Students and student teachers need to be introduced to mathematics in meaningful ways so that they would acquire conceptual understanding, value the educational and authentic relevance of mathematics and hence develop more positive attitudes and beliefs towards mathematics.

\section{References}

Akinsola, M. K., \& Ajiboye, J. O. (2009). School reform: A case study of primary education in Botswana. In James, V. U., \& Etim, J.S. (Eds.), Educational Reform in Africa: Essays on Curriculum, Libraries, Counseling, and Grades Levels. The Edwin Mellen Press, 225- 234.

Aldridge, S., \& Bobis, J. (2001). Multiple learning contexts: A vehicle for changing preservice teachers' mathematical beliefs, knowledge and practices. In J. Bobis, B.Perry, \& M. Mitchelmore (Eds.), Numeracy and beyond (Proceedings of the 24th annual conference of Mathematics Education Research Group of Andralasia Inc. (pp. 43-49) Sydney: MERGA.

Alexander, V., \& Maeda, Y. (2015). Understanding student achievement in mathematics and science: The case of Trinidad and Tobago. Prospects, 45(4), 577-591. http://dx.doi.org/10.1007/s11125-015-9373-y

Ball, D. L., Hill, H. C., \& Bass, H. (2005). Knowing mathematics for teaching. Who knows mathematics well enough to teach third grade, and how can we decide? American Educator, 29(1), 14-17, 20-22, 43-46.

Bayraktar, S. (2011). Turkish Preservice Primary School Teachers' Science Teaching Efficacy Beliefs and Attitudes Toward Science: The Effect of a Primary Teacher Education Program. School Science and Mathematics, 111(3), 83-92. http://dx.doi.org/10.1111/j.1949-8594.2010.00065.x

Bhargava, A., \& Pathy, M. K. (2014). Attitude of student teachers towards teaching profession. Turkish Online Journal of Distance Education, 15(3), 27-36. http://dx.doi.org/10.17718/tojde.15072

Bramald, R., Hardman, F., \& Leat, D. (1995). Initial teacher trainees and their views of teaching and learning. Teaching and Teacher Education, 11(1), 23-31.

Caribbean Examination Council (CXC). 2015. Report on Performances of students. Retrieved from https://www.cxc.org/annual-reports/2015/7.html

Curtis, K.M. (2006). Improving student attitudes. A study of a mathematics curriculum Innovation. Kansas State University. Retrieved from https: //krex.k-state.edu/dspace/bitstream/handle/2097/151/KarenaCurtis2006.pdf?

DeBellis, V., \& Goldin, G.A. (1999). Aspects of affect: mathematical intimacy, mathematical integrity. Proceedings of PME, 25(2), 249-256.

Dembo, M. (2001). Learning to teach is not enough. Future teachers also need to learn how to learn. Teacher Education Quarterly, 28, 23-35.

Ercikan, K., McCreith, T., \& Lapointe, V. (2005). Factors associated with mathematics achievement and participation in advanced mathematics courses: An examination of gender differences from an international 
perspective. School Science and Mathematics, 105(1), 5-14

Ernest, P. (1989). The knowledge, beliefs, and attitudes of the mathematics teacher: A model. Journal of education for teaching, 15(1), 13-34.

Fennema, E., \& Sherman, J. (1976). Fennema - Sherman mathematics attitude scales: Instruments designed to measure attitudes towards the learning of mathematics by females and males. Psychological Documents (Ms No. 1225). Washington, DC: American Psychological Association.

Furinghetti, F., \& Pehkonen, E. (2000). A comparative study of students' beliefs concerning their autonomy of doing mathematics. NOMAD, 8(4), 7-26.

Gilroy, M. (2002). Waking up students' math/science attitudes and achievement, The Education Digest, 68(4), 39-44.

Grootenboer, P. J. (2003b). Preservice primary teachers' affective development in mathematics. Unpublished doctoral dissertation, University of Waikato, NZ.

Grootenboer, P., \& Lowrie, T. (2002). Pre-service primary school teachers views on mathematics and mathematics education. Mathematics education for a knowledge-based era (Proceedings of the 2nd East Asia regional conference on mathematics education and 9th Southeast Asian conference on mathematics education, pp. 232-238). Singapore: National Institute of Education.

Imai, T. (1993). Causal relationships between mathematics achievement, attitudes toward mathematics and perceptions of mathematics teachers on secondary school students. In I. Hirabayashi, N. Nohda, K. Shigematsu, \& Lin F.-L. (Eds.), Proceedings of the 17th conference of the International Group for the Psychology of Mathematics Education, 1, pp. 245-251). Ibaraki, Japan: PME

Jacobs, K. (2012). A call for action to address performance in mathematics. Retrieved from http://www.cxc.org

Kainuwa, A., \& Yusuf, N. B. M. (2013). Influence of socio-economic and educational background of parents on their children's education in Nigeria. International Journal of Scientific and Research Publications, 3(10), 1-7.

Khan, S. (2008, February 02). A tale of 2 math teachers. Daily Express, pp. 4.

Levpuscek, M. P., \& Zupancic, M. (2013). Predicting achievement in mathematics in adolescent students: The Role of individual and social factors. The Journal of Early Adolescence, 33, 523-551. http://dx.doi.org/10.1177/0272431612450949

Lowrie, T., \& Jorgensen, R. (2015). Pre-service teachers' mathematics content knowledge: implications for how mathematics is taught in higher education. Teaching Mathematics and Its Applications, 1-14 http://dx.doi.org/10.1093/teamat/hrv008

Maasz, J., \& Schlöglmann, W. (2009). Beliefs and attitudes in mathematics education: Newresearch results. Rotterdam: Sense publishers.

Mapolelo, D. C., \& Akinsola, M. K. (2015). Preparation of mathematics teachers: Lessons from review of literature on teachers' knowledge, beliefs, and teacher education. American Journal of Educational Research, 3(4), 505-513. http://dx.doi.org/10.12691/education-3-4-18

Martino, P., \& Zan, R. (2010). Me and maths: towards a definition of attitude grounded on students' narratives. Journal of Mathematics Teacher Education, 13(1), 27-48.

Mohamed, L., \& Waheed, H. (2011). Secondary students' attitude towards mathematics in a selected school of Maldives. International Journal of Humanities and Social Science, 1(15), 277-281.

Pantziara, M., \& Philippou, G. N. (2015). Students' Motivation in the Mathematics Classroom. Revealing Causes and Consequences. International Journal of Science and Math Education, 13, 385-411. http://dx.doi.org/10.1007/s10763-013-9502-0

Persad, P. (2009, January 26). Mathematics vital for progress. The Trinidad Guardian, pp. A 14. Philipp, R. A. (2007). Mathematics Teachers. Beliefs and Affect. In: FK Lester, Jr. (ed.), SecondHandbook of Research on Mathematics Teaching and Learning. Charlotte, NC: Information Age Publishing, 257-315.

Reynolds, A. J., \& Walberg, H. J. (1992). A structural model of science achievement and attitude: An extension to high school. Journal of Educational Psychology, 84(3), 371- 382.

Schoenfeld, A. (1985, April). Students' beliefs about mathematics and their effects on mathematical performance: A questionnaire analysis. Paper presented at the annual meeting of the American Educational Research 
Association, New Orleans, LA. (ERIC Reproduction Service Document 259950).

Schuck, S., \& Grootenboer, P. (2004). Affective issues in mathematics education. In B.Perry, G. Anthony, \& C. Diezmarm (Eds.), Research in mathematics education in Australasia 2000 - 2003 (pp. 53-74). Plaxton, QLD: Post Pressed Shulman.

Shulman, L. S. (1986). Those who understand: Knowledge growth in teaching. Education Researcher, 15, 4-14.

Singh, K., Granville, M., \& Dika, S. (2002). Mathematics and science achievement: Effects of motivation, interest, and academic engagement. The Journal of Educational Research, 95(6), 323-332.

The National Institute of Higher Education, Research, Science and Technology (NIHERST) (2006). Survey of mathematics in secondary schools. Retrieved from http://www.niherst.gov.tt/research/publications/publication-secmath.html/

Tocci, C.M., \& Engelhard, G. (1991). Achievement, parental support and gender differences in attitudes toward mathematics. Journal of Educational Research, 84, 280-286.

Uysal, F., \& Yuksel, D. (2016). Mathematics anxiety and beliefs of Turkish pre-service elementary teachers. EURASIA Journal of Mathematics, Science and Technology Education, 12(8), 2171-2186. http://dx.doi.org/10.12973/eurasia.2016.1418a

White, A. L., Perry, B., Way, J., \& Southwell, B. (2006). Mathematical attitudes, beliefs and achievement in primary pre-service mathematics teacher education. Mathematics Teacher Education and Development, 7, 33-52.

Wilkins J. L. M. (2008). The relationship among elementary teachers' content knowledge, attitudes, beliefs, and practices. J. Math Teacher Education, 11: 139-164.

Zan, R. \& Martino, P. (2008). Attitude toward mathematics: overcoming the positive/negative dichotomy. In Beliefs and Mathematics, B. Sriraman, (Ed.), The Montana Mathematics Enthusiast: Monograph Series in Mathematics Education, pp. 197-214, Age Publishing \& The Montana Council of Teachers of Mathematics, Charlotte, NC, USA.

Zevenbergen, R. (2005). The construction of a mathematical habitus: Implications of ability grouping in the middle years. Journal of Curriculum Studies, 37(5), 607-619. 